\title{
PENGARUH GAYA KEPEMIMPINAN TRANSFORMASIONAL DAN \\ KOMPENSASI TERHADAP KEPUASAN KERJA KARYAWAN RESTORAN WARUNG TAULAN BADUNG
}

\author{
Zulkarnaen ${ }^{1}$ \\ I Nyoman Sudarma ${ }^{2}$ \\ ${ }^{1,2}$ Fakultas Ekonomi dan Bisnis Universitas Udayana (Unud), Bali, Indonesia \\ e-mail: ibenzulkarnaen@gmail.com
}

\begin{abstract}
ABSTRAK
Tujuan penelitian ini adalah untuk mengetahui pengaruh gaya kepemimpinan dan kompensasi finansial terhadap kepuasan kerja karyawan Restoran Warung Taulan Badung. Penelitian ini bersifat kuantitatif asosiatif. Sumber data yang digunakan dalam penelitian ini adalah data primer dan sekunder. Metode penentuan sampel pada penelitian ini adalah sampel jenuh, sehingga sampel pada penelitian ini adalah sama dengan jumlah populasinya yaitu 31 orang. Teknik pengumpulan data menggunakan wawancara dan kuisioner. Teknik analisis data menggunakan analisis regresi linier berganda. Hasil penelitian menunjukkan kepemimpinan tranformasional dan kompensasi berpengaruh positif dan signifikan terhadap kepuasan kerja karyawan Restoran Warung Taulan Badung.
\end{abstract}

Kata kunci: gaya kepemimpinan transformasional, kompensasi finansial, kepuasan kerja

\begin{abstract}
The purpose of this study is to determine the effect of leadership style and financial compensation on job satisfaction employees of Restaurant Warung Taulan Badung. This research is quantitative associative. Sources of data used in this study are primary and secondary data. The method of determining the sample in this study is the sample saturated, so the sample in this study is the same with the number of population is 31 people. Data collection techniques used interviews and questionnaires. Data analysis technique used multiple linear regression analysis. The results showed that tranformational leadership and compensation have a positive and significant effect on employee job satisfaction Restaurant Warung Taulan Badung.
\end{abstract}

Keywords: transformational leadership style, financial compensation, job satisfaction 


\section{PENDAHULUAN}

Tujuan dari setiap perusahaan adalah meningkatkan keuntungan perusahaan. Namun dalam prakteknya sering menghadapi kendala. Salah satu kendalanya adalah ketidakpuasan kerja karywan yang dapat menghambat kinerja perusahaan. Karena itu salah satu langkah yang ditempuh perusahaan adalah mengupayakan terciptanya kepuasan kerja pegawai sebagai motivasi pencapaian hasil kerja dan keuntungan perusahaan. Dengan kata lain, produktivitas atau hasil kerja karyawan akan meningkat seiring dengan terciptanya kepuasan kerja. Kepuasan kerja karyawan merupakan faktor yang perlu diperhatikan oleh pihak manajemen sebagai upaya memelihara tingkat kinerja karyawan yang diinginkan. Kepuasan kerja menunjukan seberapa besar tingkat keseriusan dan tanggung jawab karyawan dalam menjalankan tugas yang diberikan (Siagian, 2011: 57). Kepuasan kerja yang timbul merupakan suatu pernyataan emosional yang positif atau menyenangkan sebagai akibat dari apresiasi terhadap pekerjaan dan pengalaman kerja tertentu.

Kepuasan kerja merupakan hal yang bersifat individu dan disetiap individu mempunyai tingkat kepuasan yang berbeda-beda dengan nilai-nilai yang berlaku pada dirinya, semakin banyak aspek dalam pekerjaan yang sesuai dengan keinginan maka semakin tinggi tingkat kepuasan yang dirasakan, karyawan yang merasa puas dengan pekerjaan mereka cenderung kreatif dan inovatif yang membantu perusahaan untuk tumbuh, berkembang dan inovatif yang membantu perusahaan untuk tumbuh, berkembang dan akan membawa perubahan positif bagi perusahaan. 
Tingkat kepuasan kerja dicapai apabila harapan dan kebutuhan karyawan selaras dengan kenyataaan yang dirasakan. Peningkatan kepuasan kerja yang dirasakan karyawan tersebut akan diiringi dengan meningkatnya kinerja karyawan. Namun sebaliknya, ketidakpuasan seorang karyawan melahirkan beberapa perilaku agresif karyawan seperti melakukan sabotase, sengaja melakukan kesalahan kerja, pemogokan, dan suka membolos, dimana hal tersebut pada akhirnya akan menurunkan kinerja mereka (Prabu, 2005).

Kepemimpinan sangat menentukan kemajuan dan kemunduran organisasi (Muhammad et al., 2012). Gibson et al. (1996) mendifinisi kepemimpinan sebagai suatu upaya penggunaan jenis pengaruh bukan paksaan (concoersive) untuk orang-orang mencapai tujuan tertentu. Elemen-elemen kerja yang berhubungan dengan kepuasan kerja diantaranya adalah nilai kompensasi, promosi kerja, kondisi kerja, supervisi, cara kerja organisasi dan hubungan yang tercipta antara atasan dan bawahan (Mosadeghard dan Yarmohammadian, 2006).

Gaya kepemimpinan transformasional yaitu dimana pemimpin memberikan perhatiannya kepada persoalan-persoalan yang dihadapi oleh para pengikutnya serta kebutuhan pengembangan dari masing-masing pengikutnya dengan cara memberikan semangat (Wahjosumidjo, 2003:278). Menurut Siagian (2011:57) seorang pemimpin harus dapat mewujudkan rasa puas karyawan dalam bekerja. Adanya penerapan gaya kepemimpinan transformasional akan membuat bawahan merasa loyal, respek kepada atasannya dan pada akhirnya bawahan akan termotivasi melakukan lebih dari yang diharapkan (Alam dkk., 2013). Hasil penelitian yang dilakukan Yang et al. (2012) menunjukan bahwa gaya 
kepemimpinan transformasional berpengaruh positif dan siginifikan terhadap kepuasan karyawan.

Kompensasi merupakan salah satu indikator dari kepuasan kerja yang dimana kompensasi finansial ini dimaksud adalah balas jasa baik berupa uang, barang maupun kenikmatan yang diberikan oleh sebuah perusahaan dimana karyawan itu bekerja atas kinerja yang disumbangkan kepada perusahaan (Gorda, 2006:190). Ardana dkk. (2012:154) menyatakan faktor dan tujuan pemberian kompensasi adalah untuk tujuan ikatan kerjasama, kepuasan kerja karyawan, pengadaan yang efektif, motivasi, stabilitas karyawan, disiplin kerja karyawan, menghindarkan pengaruh serikat buruh dan menghindarkan intervensi dari pemerintah.

Penelitian yang dilakukan oleh Oktaviane (2013), membuktikan bahwa kompensasi berpengaruh positif terhadap kepuasan kerja. Begitu pula penelitian yang di lakukan oleh Nawab dan Bhatti (2011) juga membuktikan bahwa kompensasi mempunyai hubungan dengan kepuasan kerja. Akan tetapi penelitian yang di lakukan oleh Ural (2008), membuktikan bahwa kompensasi tidak mempunyai pengaruh yang signifikan terhadap kepuasan kerja.

Warung Taulan adalah usaha yang berjenis restoran. Warung Taulan sendiri berlokasi di Banjar Pengubengan Kaja Krobokan kabupaten Badung. Warung Taulan didirikan pada tahun 2011 oleh Nengah Wiratha. Warung Taulan saat ini memiliki total karyawan sebanyak 31 (Tabel 1). 
Tabel 1

Jumlah Karyawan Warung Taulan

\begin{tabular}{|c|c|c|}
\hline No. & Jabatan & Jumlah Karyawan \\
\hline 1 & Akuntan & $x_{0}$ \\
\hline 2 & Head chef & 1 \\
\hline 3 & Chef & 6 \\
\hline 4 & Kasir & 3 \\
\hline 5 & Waitress & 13 \\
\hline 6 & Satpam & 4 \\
\hline 7 & Supir & 3 \\
\hline & Total & 31 \\
\hline
\end{tabular}

Sumber : Data diolah, 2017

Hasil dari wawancara dengan 12 karyawan, ditemukan beberapa permasalahan yang muncul pada pengelolaan sumber daya manusia (SDM) Warung Taulan yang menyangkut dengan ketidakpuasan kerja pada karyawan tersebut, yaitu sebagai berikut: 1) cara pemberian motivasi pimpinan/atasan terhadap karyawan/bawahannya. Pimpinan kerap memberi tekanan dalam pemberian arahan terhadap karyawan ketika karyawan melakukan sedikit kesalahan, 2) kompensasi yang dianggap kurang bagi sebagian besar karyawan. Kondisi ini dikarenakan terkadang penjualan sedang ramai saat liburan yang membuat karyawan untuk lembur.

Berdasarkan uraian pada latar belakang, maka dapat di susun rumusan masalah sebagai berikut: 1) bagaimana pengaruh gaya kepemimpinan transformasional terhadap kepuasan kerja karyawan, 2) bagaimana pengaruh kompensasi terhadap kepuasan kerja karyawan. Berdasarkan latar belakang dan rumusan masalah yang telah dikemukakan maka tujuan yang ingin dicapai dalam penelitian berikut adalah 1) untuk mengetahui pengaruh gaya kepemimpinan transformasional terhadap kepuasan kerja karyawan Restoran Warung Taulan 
Badung, 2) untuk mengetahui pengaruh kompensasi terhadap kepuasan kerja karyawan Restoran Warung Taulan Badung.

Hasil penelitian ini diharapkan mampu memberikan manfaat baik secara teoritis maupun praktis bagi pihak-pihak yang berkaitan di dalam penelitian ini, antara lain: 1) Kegunaan Teoritis, penelitian ini diharapkan dapat memberikan pengetahuan dan bukti-bukti empiris tentang pengaruh kepemimpinan transformasional dan kompensasi terhadap kepuasan kerja. Penelitian ini juga dapat dijadikan media pelatihan dan referensi untuk menerapkan teori-teori yang berhubungan dengan materi penelitian ini, 2) Kegunaan Praktis, penelitian ini diharapkan dapat memberikan kegunaan praktis yaitu sebagai bahan pertimbangan dalam meningkatkan dan memberikan masukan yang akurat kepada perusahaan.

Kepuasan kerja adalah cara pandang seseorang baik yang bersifat positif maupun bersifat negatif tentang suatu pekerjannya (Siagian, 2011:295). Rezvan et al. (2013), menjelaskan bahwa perusahaan membutuhkan karyawan yang mampu bekerja lebih baik dan lebih cepat, untuk mendapatkan hal tersebut kepuasan kerja karyawan harus dipelihara dan diperhatikan. Menurut Martoyo (2007:156) kepuasan kerja adalah keadaan emosional karyawan dimana terjadi ataupun tidak terjadi titik temu antara nilai balas jasa kerja karyawan dari perusahaan atau organisasi dengan tingkat nilai balas jasa yang memang diinginkan oleh karyawan yang bersangkutan. Kepuasan kerja juga merupakan keadaan emosional yang menyenangkan atau tidak menyenangkan dimana pada saat karyawan memandang pekerjaan mereka (Handoko,2010). Luthans (2005), menyatakan beberapa 
dimensi terjadinya suatu kepuasan kerja, yaitu: Pekerjaan itu sendiri, gaji, promosi jabatan, pengawasan, dan rekan kerja.

Pemimpin transformasional adalah pemimpin yang memotivasi pengikut melalui inspirasi (Zahari, 2012). Para pengikut yang ditawarkan tantangan dan dukungan pengembangan kepribadian, berwujud konsentrasi pada kualitas seperti ide-ide, nilai-nilai dan visi dalam upaya membangun hubungan baik dalam organisasi (Maulizar dkk., 2012). Kepemimpinan transformasional menurut Bass (2003) adalah pemimpin yang memotivasi pengikut melalui inspirasi. Adapun indikator kepemimpinan transformasional adalah sebagai berikut: Pengaruh yang diidealisasikan, motivasi inspirasional, stimulasi intelektual, dan pertimbangan individual.

Menurut Utama (2001:261) pemberian kompensasi merupakan sebuah balas jasa yang diberikan perusahaan baik berupa uang, barang, maupun kenikmatan yang diberikan oleh perusahaan kepada karyawan atas kepuasan kerja yang disumbangkan kepada perusahaan. Kompensasi adalah pembayaran kepada karyawan dalam bentuk finansial, seperti yang langsung berupa gaji, komisi dan bonus, serta yang tidak langsung berupa asuransi, bantuan sosial, uang cuti, uang pensiun dan pendidikan (Mangkuprawira, 2002:196). Menurut Hasibuan (2007:118) kompensasi memiliki tiga komponen, yaitu sebagai berikut: Pembayaran secara langsung, pembayaran tidak langsung, dan ganjaran non finansial. Simamora (2006:445) menyatakan indikator-indikator kompensasi adalah sebagai berikut: upah dan gaji, insentif, tunjangan, dan fasilitas. 
Menurut Yang (2012) berpendapat bahwa kepemimpinan transformasional berpengaruh positif secara signifikan terhadap kepuasan kerja intrinsik dan ekstrinsik bawahan. Zahari (2012) mengatakan ada hubungan yang positif dan signifikan antara gaya kepemimpinan transformasional terhadap kepuasan kerja karyawan. Al-Swidi et al. (2012) mengatakan bahwa kepemimpinan transformasional telah terbukti memiliki efek signifikan pada kepuasan kerja karyawan melalui peningkatan persepsi pemberdayaan karyawan. Voon (2011) yang menyatakan bahwa kepemimpinan yang bergaya transformasional memiliki pengaruh positif terhadap kepuasan kerja karyawan.Berdasarkan landasan teori dan berbagai penelitian sebelumnya dapat dikemukakan hipotesis sebagai berikut:

$\mathrm{H}_{1}$ : Kepemimpinan transformasional berpengaruh positif terhadap kepuasan kerja karyawan.

Penelitian yang dilakukan oleh Syah (2013) menyatakan bahwa kompensasi teruji berpengaruh positif terhadap kepuasan kerja dan motivasi kerja karyawan pada PT. Graha Raja Empat. Penelitian yang dilakukan oleh Islam dkk. (2012) menyatakan bahwa ada hubungan positif antara kompensasi dan kepuasan kerja. Penelitian Siregar (2011) menyatakan bahwa kompensasi berpengaruh positif terhadap kepuasan kerja.

$\mathrm{H}_{2}$ : Kompensai berpengaruh positif terhadap kepuasan kerja karyawan.

\section{METODE PENELITIAN}

Penelitian ini bersifat kuantitatif asosiatif yang bertujuan untuk mengetahui pengaruh atau hubungan antara dua variabel atau lebih (Sugiyono, 2012:5). Penelitian ini dilakukan untuk mengetahui pengaruh 
kepemimpinantransformasional dan kompensasiterhadap kepuasan kerja karyawan. Data yang diperoleh akan diolah agar dapat membuktikan hipotesis dan menjawab rumusan masalah yang telah dibuat sebelumnya.Warung Taulam bertempat di Banjar Pengubengan Kaja, Kabupaten Badung. Objek dalam penelitian ini adalah kepemimpinan transformasional, kompensasi dan kepuasan kerja. Subyek dalam penelitian ini adalah para karyawan pada Warung Taulan. Variable-variabel yang dianalisis dalam penelitian ini terdiri dari variable dependen dan variabel independen, yaitu sebagai berikut: variabel terikat dalam penelitian ini adalah kepuasan kerja (Y). Variabel bebas dalam penelitian ini adalah kepemimpinan transformasional dan kompensasi (X).

Siagian (2011: 295) mengatakan kepuasan kerja adalah cara pandang seseorang baik yang bersifat positif maupun bersifat negatif tentang suatu pekerjannya. Luthans (2005), menyatakan beberapa dimensi terjadinya suatu kepuasan kerja, yaitu: 1) Pekerjaan itu sendiri, indikator ini diukur dari persepsi resonden mengenai pekerjaan saat ini sesuai dengan keahliannya, 2) Gaji, indikator ini diukur dari persepsi responden mengenai gaji yang diterima sudah sesuai dengan beban kerja yang diberikan peruahaan, 3) Promosi jabatan, indikator ini diukur dari persepsi responden mengenai kepuasan dengan kesempatan untuk memperoleh promosi kenaikan jabatan, 4) Pengawasan, indikator ini diukur dari persepsi responden mengenai bagaimana pemimpin dalam memberikan arahan, 5) Rekan kerja, indikator ini diukur dari persepsi responden mengenai hubungan kerja sama mereka dengan rekan kerja ditempat mereka bekerja sudah terjalin dengan baik. 
Kepemimpinan transformasional menurut Bass dalam Zahari (2012) adalah kepemimpinan yang memotivasi pengikut melalui inspirasi. Adapun indikator kepemimpinan transformasional adalah sebagai berikut: 1) Pengaruh yang diidealisasikan, pemimpin memiliki kharisma untuk mewujudkan bahwa pemimpin memiliki pendirian yang kuat, serta komitmen dalam memimpim perusahaan, 2) Motivasi inspirasional, pemimpin mempunyai motivasi yang menarik untuk memberikan dorongan terhadap apa yang perlu dilakukan oleh karyawan, 3) Stimulasi intelektual, pemimpin yang memberi inspirasi bawahannya untuk lebih kreatif mengeluarkan ide-idenya dalam menyelesaikan permasalahan yang ada, 4) Pertimbangan Individual, pemimpin memberikan perhatian dalam langkah mengajarkan individu untuk lebih berkembang dan berprestasi dengan bertindak sebagai pelatih.

Menurut Utama (2001:261) kompensasi merupakan sebuah balas jasa yang diberikan perusahaan baik berupa uang, barang, maupun kenikmatan yang diberikan oleh perusahaan kepada karyawan atas kepuasan kerja yang disumbangkan kepada perusahaan. Simamora (2006 : 445) menyatakan indikatorindikator kompensasi adalah sebagai berikut: 1) Gaji adalah suatu bentuk imbalan kerja berupa uang yang diterima karyawan untuk setiap periode tanpa memperhatikan jumlah jam kerja. Sedangkan upah adalah imbalan kerja yang diberikan oleh perusahaan yang dihitung secara langsung berdasarkan pada jumlah waktu kerja, 2) Insentif adalah suatu penghargaan dalam bentuk finansial diluar gaji yang diberikan perusahaan kepada karyawan agar mereka bekerja dengan motivasi yang tinggi dan berprestasi dalam pencapaian tujuan organisasi, 3) Tunjangan adalah suatu penghargaan tidak langsung yang diberikan oleh 
perusahaan kepada karyawan sebagai bagian dari keanggotaan organisasi tanpa menghiraukan kinerja, 4) Fasilitas adalah sarana dan prasana yang diberikan oleh perusahaan untuk memudahkan pekerjaan karyawan seperti peralatan kantor, transportasi, dan alat komunikasi.

Data kuantitatif dalam penelitian ini adalah jumlah karyawan dan skor jawaban responden terhadap kuesioner. Data kualitatif dalam penelitian ini seperti struktur organisasi, aktivitas perusahaan dan sejarah perusahaan. Data primer dalam penelitian ini berupa kuisioner yang didapatkan langsung melalui pengisian kuesioner oleh responden yaitu Warung Taulan. Data sekunder dalam penelitian ini seperti jumlah karyawan, profil sejarah perusahaan, dan struktur organisasi perusahaan.

Metode penentuan sampel dalam penelitian ini adalah sampel jenuh. Sampel jenuh adalah teknik penentuan sampel apabila semua anggota populasi digunakan sebagai sampel (Sugiyono, 2009:68). Populasi dalam hal ini seluruh karyawan di Warung Taulan berjumlah 31 orang. Pemilihan sampel ini telah mewakili populasi dengan batas minimum sampel suatu penelitian. Jumlah responden yang akan dilibatkan sebagai sampel dalam penelitian ini adalah sebanyak 31 responden. Penggunaan metode ini berlaku jika jumlah populasi yang digunakan relatif kecil dan mudah dijangkau. Pengumpulan data dalam penelitian dilakukan dengan menggunakan metode wawancara dan kuesioner.

Uji validitas instrumen dilakukan untuk mengukur keandalan dan ketepatan instrumen yang digunakan, instrumen yang valid merupakan instrumen yang benar-benar tepat untuk mengukur apa yang hendak diukur (Sugiyono, 2012:172). 
Ketentuan suatu instrumen dikatakan valid apabila nilai korelasi Pearson Product Moment r-hitung > r-tabel atau (r) > 0,361 telah terpenuhi (Sugiyono, 2012:348). Uji Reliabilitas dilakukan untuk mengukur suatu kuesioner yang merupakan indikator dari setiap variabel. Pengujian reliabilitas dilakukan dengan menggunakan Cronbach Alpha, koefisien Cronbach Alpha yang melebihi angka dari 0,6 menunjukkan keandalan (reliabilitas) suatu instrumen (Sugiyono 2012:456). Dalam penelitian ini, untuk menguji realibilitas dengan tehnik analisis dengan formula Cronbach's Alpha dengan bantuan komputer.

Menurut Sugiyono (2010: 277) teknik analisis linear berganda digunakan oleh peneliti, bila peneliti bermaksud meramalkan bagaimana keadaan (naik turunnya) variabel dependen, bila dua atau lebih variabel independen sebagai faktor predictor dimanipulasi (dinaik turunkan nilainya). Analisis regresi ganda akan dilakukan bila jumlah variabel independennya minimal dua. Adapun bentuk umum dari persamaan teknik analisis regresi linear berganda adalah sebagai berikut.

$\mathrm{Y}=\mathrm{a}+\beta_{1} \mathrm{X}_{1}+\beta_{2} \mathrm{X}_{2}+\mathrm{e}$

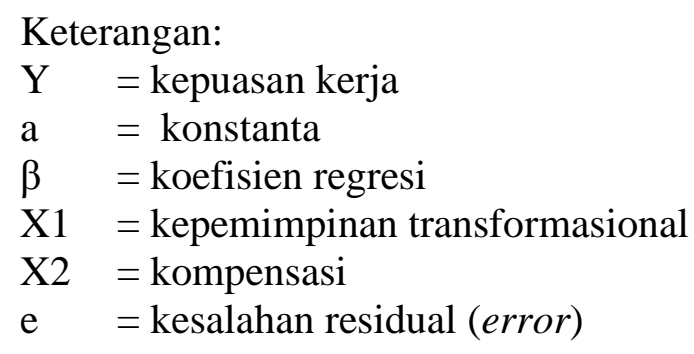

Penelitian ini menggunakan statistik parametrik dengan model regresi berganda, maka sebelumnya perlu dilakukan uji asumsi klasik yang meliputi 1) uji normalitas bertujuan untuk menguji apakah suatu residual data berdistribusi 
normal atau tidak, 2) uji multikolinearitas bertujuan untuk menguji apakah dalam model regresi ditemukan adanya kolerasi antara variabel-variabel bebas dengan melihat nilai tolerance atau VIF, 3) uji heteroskedastisitas menurut (Ghozali, 2006:105) merupakan suatu uji yang bertujuan untuk menguji apakah dalam model regresi terjadi ketidaksamaan varians dari residual satu ke pengamatan yang lain tetap maka disebut homokedasitas jika berbeda disebut heteroskedastisitas. Metode yang digunakan untuk menguji adanya heteroskedastisitas adalah uji Glejser, yaitu dengan melihat nilai signifikan variabl bebas dimana nilainya harus lebih besar dari 0,05 .

Koefisien determinasi $\left(\mathrm{R}^{2}\right)$ digunakan untuk mengukur kemampuan model regresi dalam menerangkan variasi variabel bebas. Nilai koefisien determinasi adalah antara nol dan satu. Nilai $\mathrm{R}^{2}$ yang kecil berarti kemampuan variabelvariabel bebas dalam menjelaskan variasi variabel terikat amat terbatas. Nilai yang mendekati satu berarti variabel-variabel bebas memberikan hampir semua informasi yang dibutuhkan untuk memprediksi variasi variabel terikat. Uji statistik F digunakan untuk mengetahui kelayakan model regresi linier berganda sebagai alat analisis pengujian tentang pengaruh variabel bebas terhadap variabel terikat. Bila signifikansi pada tabel annova lebih kecil daripada $\alpha=0,05$ maka model ini layak atau fit. Uji statistik t digunakan untuk mengetahui pengaruh satu variabel bebas secara individual atau parsial dalam menjelaskan variasi variabel terikat (Ghozali, 2006:88). Pengujian dilakukan dengan menggunakan taraf signifikansi sebesar $\alpha=0,05$. Apabila tingkat signifikansi variabel bebas kurang 
dari tingkat signifikansi $\alpha=0,05$, maka dapat dikatakan bahwa variabel bebas berpengaruh signifikan terhadap variabel terikat.

\section{HASIL DAN PEMBAHASAN}

Berdasarkan hasil penyebaran kuesioner yang dilakukan, maka diketahui gambaran tentang karakteristik responden seperti yang disajikan pada Tabel 2.

Tabel 2.

Karakteristik Responden

\begin{tabular}{|c|c|c|c|}
\hline Variabel & $\begin{array}{c}\text { Klasifikasi } \\
\text { Jenis kelamin }\end{array}$ & $\begin{array}{l}\text { Jumlah } \\
\text { (Orang) }\end{array}$ & $\begin{array}{c}\text { Persentase } \\
(\%)\end{array}$ \\
\hline \multirow[t]{2}{*}{ Jenis kelamin } & Laki-laki & 21 & 67,7 \\
\hline & Perempuan & 10 & 32,3 \\
\hline \multicolumn{2}{|c|}{ Jumlah } & 31 & 100 \\
\hline Variabel & Klasifikasi umur & $\begin{array}{l}\text { Jumlah } \\
\text { (Orang) }\end{array}$ & $\begin{array}{c}\text { Persentase } \\
(\%)\end{array}$ \\
\hline \multirow[t]{4}{*}{ Umur } & 20-30 tahun & 21 & 67,7 \\
\hline & $31-40$ tahun & 6 & 19,4 \\
\hline & $\geq 41$ tahun & 4 & 12,9 \\
\hline & Jumlah & 31 & 100 \\
\hline Variabel & $\begin{array}{c}\text { Klasifikasi } \\
\text { Pendidikan terakhir }\end{array}$ & $\begin{array}{l}\text { Jumlah } \\
\text { (orang) }\end{array}$ & $\begin{array}{c}\text { Persentase } \\
(\%)\end{array}$ \\
\hline \multirow[t]{4}{*}{ Pendidikan Terakhir } & SMA/SMK & 21 & 67,7 \\
\hline & D1 & 7 & 19,4 \\
\hline & $\mathrm{S} 1$ & 3 & 12,9 \\
\hline & lah & 31 & 100 \\
\hline
\end{tabular}

Sumber: Data diolah, 2017

Berdasarkan Tabel 2 karyawan laki-laki jumlah nya dua kali lipat dari perempuan (67\%). Berdasarkan data tersebut dapat diketahui bahwa jumlah karyawan laki-laki lebih banyak dipekerjakan di Restoran Warung Taulan di Bali. Hal ini disebkan oleh keadaan restoran yang cukup ramai sehingga karyawan laki yang memiliki tenaga lebih besar dari perempuan lebih dibutuhkan. Responden berdasarkan umur di dominasi kisaran umur 20-30 tahun yang berjumlah 21 orang atau sebesar 67,7 persen. Responden dengan umur 31-40 tahun berjumlah 6 orang 
atau 19,4 persen. Responden paling sedikit adalah responden umur $>41$ tahun berjumlah 4 orang dengan atau sebesar 12,9 persen. Dominannya karyawan dengan umur 20-30 tahun dikarenakan restoran mambutuhan karyawan yang lebih muda agar restoran tersebut terlihat lebih fresh. Berdasarkan tingkat pendidikannya responden penelitian adalah SMA/SMK, D1, dan S1, dimana mayoritas responden penelitian memiliki tingkat pendidikan SMK/SMA yaitu sebanyak 21 orang atau sebesar 67,7 persen. Pendidikan D1 sebanyak 7 orang atau sebesar 19,4 persen. Responden dengan tingkat pendidikan S1 sebanyak 3 orang atau sebesar 12,9 persen. Banyaknya karyawan dengan tingkat pendidikan SMA/SMK disebabkan jumlah karyawan dibagian pelayan lebih banyak dibandingkan dengan bagian lain, karena tidak terlalu dibutuhkan pendidikan yang tinggi pada sektor ini.

Penelitian dilakukan dengan mengajukan kuesioner dimana variabel gaya kepemimipinan terdiri dari 4 pernyataan, kompensasi sebanyak 4 pernyataan dan kepuasan kerjaterdiri dari 5 pernyataan. Untuk mendapatkan penilaian secara kualitatif dipergunakan skor rata-rata jawaban responden dengan kriteria dan kategori penilaian jawaban kuisioner seperti Tabel 3.

Tabel 3.

Kriteria Penilaian Jawaban Kuisioner Gaya Kepemimpinan Tranformasional, Kompensasi, Kepuasan kerja

\begin{tabular}{|c|c|}
\hline Kriteria & Kategori Penilaian \\
\hline $1,00-1,80$ & Sangat kurang baik \\
\hline $1,81-2,60$ & Kurang baik \\
\hline $2,61-3,40$ & Cukup baik \\
\hline $3,41-4,20$ & Baik \\
\hline $4,21-5,00$ & Sangat baik \\
\hline
\end{tabular}


Tabel 4.

Distribusi Tanggapan Responden Pada Variabel Gaya Kepemimipinan Tranformasional

\begin{tabular}{llllllllll}
\hline \multirow{2}{*}{ No } & \multirow{2}{*}{ Pernyataan } & \multicolumn{9}{c}{ Jawaban Responden } & \multirow{2}{*}{ Skor } & \multirow{2}{*}{$\begin{array}{l}\text { Rata- } \\
\text { Rata }\end{array}$} \\
\cline { 3 - 8 } & & SS & S & CS & TS & STS & & \\
\hline 1 & X1.1 & 3 & 22 & 1 & 5 & 0 & 116 & 3,74 \\
2 & X1.2 & 3 & 22 & 2 & 4 & 0 & 117 & 3,77 \\
3 & X1.3 & 3 & 20 & 3 & 5 & 0 & 114 & 3,68 \\
4 & X1.4 & 3 & 19 & 4 & 5 & 0 & 113 & 3,65 \\
\hline & Rata-rata & & & & & & & $\mathbf{3 , 7 1}$ \\
\hline
\end{tabular}

Sumber: Data diolah, 2017

Berdasarkan Tabel 4, terlihat bahwa rata-rata skor dari 4 pernyataan mengenai gaya kepemimipinan tranformasional yaitu sebesar 3,71 yang berada pada kisaran 3,41 - 4,20 yang berarti baik.

Tabel 5.

Distribusi Tanggapan Responden Pada Variabel Kompensasi

\begin{tabular}{|c|c|c|c|c|c|c|c|c|}
\hline \multirow{2}{*}{ No } & \multirow{2}{*}{ Pernyataan } & \multicolumn{5}{|c|}{ Jawaban Responden } & \multirow{2}{*}{ Skor } & \multirow{2}{*}{$\begin{array}{l}\text { Rata- } \\
\text { Rata }\end{array}$} \\
\hline & & SS & $\mathbf{S}$ & CS & TS & STS & & \\
\hline 1 & $\mathrm{X} 2.1$ & 3 & 17 & 3 & 8 & 0 & 108 & 3,48 \\
\hline 2 & $\mathrm{X} 2.2$ & 3 & 15 & 3 & 10 & 0 & 104 & 3,35 \\
\hline 3 & $\mathrm{X} 2.3$ & 3 & 14 & 6 & 8 & 0 & 105 & 3,39 \\
\hline \multirow[t]{2}{*}{4} & $\mathrm{X} 2.4$ & 3 & 16 & 3 & 9 & 0 & 106 & 3,41 \\
\hline & Rata-rata & & & & & & & 3,41 \\
\hline
\end{tabular}

Sumber : Data diolah, 2017

Berdasarkan Tabel 5, terlihat bahwa rata-rata skor dari 4 pernyataan mengenai kompensasi yaitu sebesar 3,41 yang berada pada kisaran 3,41 - 4,20 yang berarti baik. Artinya bahwa karyawan pada Restoran Warung Taulan di Bali yang menjadi responden dalam penelitian ini menilai kompensasi kerja dalam katogori yang baik. 
Tabel 6.

Distribusi Tanggapan Responden Pada Variabel Kepuasan Kerja

\begin{tabular}{|c|c|c|c|c|c|c|c|c|}
\hline \multirow{2}{*}{ No } & \multirow{2}{*}{ Pernyataan } & \multicolumn{5}{|c|}{ Jawaban Responden } & \multirow{2}{*}{ Skor } & \multirow{2}{*}{$\begin{array}{l}\text { Rata- } \\
\text { Rata }\end{array}$} \\
\hline & & SS & $\mathbf{S}$ & CS & TS & STS & & \\
\hline 1 & Y2.1 & & & 18 & 13 & & 80 & 2,58 \\
\hline 2 & Y 2.2 & & 2 & 7 & 21 & 1 & 72 & 2,32 \\
\hline 3 & $\mathrm{Y} 2.3$ & & 2 & 13 & 15 & 1 & 78 & 2,52 \\
\hline 4 & Y2.4 & & 2 & 15 & 13 & 1 & 80 & 2,58 \\
\hline 5 & Y2.5 & & 1 & 19 & 10 & 1 & 82 & 2,65 \\
\hline
\end{tabular}

Sumber: Data diolah, 2017

Berdasarkan Tabel 6, terlihat bahwa rata-rata skor dari 5 pernyataan mengenai kepuasan kerja yaitu sebesar 2,53 yang berada pada kisaran 2,60 - 3,20 yang berarti cukup baik. Artinya, karyawan pada Restoran Warung Taulan di Bali yang menjadi responden dalam penelitian ini menilai kepuasan kerjaadalah cukup baik.

Uji validitas digunakan untuk mengukur sah atau valid tidaknya suatu kuesioner. Suatu kuesioner dikatakan valid jika pertanyaan pada kuesioner mampu untuk mengungkapkan sesuatu yang akan diukur oleh kuesioner tersebut. Valid tidaknya suatu instrument dilihat dari nilai koefisien korelasi, yaitu dengan kriteria nilai koefisien korelasi memiliki nilai diatas 0,3 . Uji validitas pada penelitian ini dilakukan terhadap variabel gaya kepemimipinan tranformasional, kompensasi, dan kepuasan kerja. Hasil uji disajikan pada Tabel 7, Tabel 8 dan Tabel 9. Berdasarkan Tabel 7 diketahui bahwa seluruh indikator dalam variabel gaya kepemimipinan tranformasional memiliki koefisien korelasi yang lebih besar 
dari 0,3 . Jadi dapat disimpulkan bahwa seluruh indikator telah memenuhi syarat validitas data.

Tabel 7.

Hasil Uji Validitas Variabel Gaya Kepemimipinan Tranformasional (X1)

\begin{tabular}{cccc}
\hline No & Indikator & Koefisien Korelasi & Keterangan \\
\hline 1 & $\mathrm{X} 1.1$ & 0,936 & Valid \\
2 & $\mathrm{X} 1.2$ & 0,944 & Valid \\
3 & $\mathrm{X} 1.3$ & 0,915 & Valid \\
4 & $\mathrm{X} 1.4$ & 0,906 & Valid \\
\hline \multicolumn{2}{l}{ Sumber: } & Data diolah, 2017
\end{tabular}

Berdasarkan Tabel 8 diketahui bahwa seluruh indikator dalam variabel kompensasi memiliki koefisien korelasi yang lebih besar dari 0,3. Jadi dapat disimpulkan bahwa seluruh indikator telah memenuhi syarat validitas data.

Tabel 8.

Hasil Uji Validitas Variabel Kompensasi (X2)

\begin{tabular}{clcrr}
\hline No & & Indikator & Koefisien Korelasi & \multicolumn{2}{c}{ Keterangan } \\
\hline 1 & $\mathrm{X}_{2.1}$ & 0,978 & Valid \\
2 & $\mathrm{X}_{2.2}$ & 0,932 & Valid \\
3 & $\mathrm{X}_{2.3}$ & 0,932 & Valid \\
4 & $\mathrm{X}_{2.4}$ & 0,944 & Valid \\
\hline \multicolumn{2}{l}{ Sumber: } & Data diolah, 2017
\end{tabular}

Berdasarkan Tabel 9 diketahui bahwa seluruh indikator dalam variabel kepuasan kerja memiliki koefisien korelasi yang lebih besar dari 0,3, dimana untuk indikator $\mathrm{Y}_{1}$ dengan nilai koefisien korelasi sebesar $0,717, \mathrm{Y}_{2}$ sebesar 0,776, $\mathrm{Y}_{3}$ sebesar 0,887, $\mathrm{Y}_{4}$ sebesar 0,809, dan $\mathrm{Y}_{5}$ sebesar 0,866. Jadi dapat disimpulkan bahwa seluruh indikator telah memenuhi syarat validitas data dan layak digunakan. 
Tabel 9.

Hasil Uji Validitas Variabel Kepuasan Kerja (Y)

\begin{tabular}{|c|c|c|c|}
\hline No & Indikator & Koefisien Korelasi & Keterangan \\
\hline 1 & $\mathrm{Y}_{1}$ & 0,717 & Valid \\
\hline 2 & $\mathrm{Y}_{2}$ & 0,776 & Valid \\
\hline 3 & $\mathrm{Y}_{3}$ & 0,887 & Valid \\
\hline 4 & $\mathrm{Y}_{4}$ & 0,809 & Valid \\
\hline 5 & $\mathrm{Y}_{5}$ & 0,866 & Valid \\
\hline
\end{tabular}

Reliabilitas adalah alat untuk mengukur suatu kuesioner yang merupakan indikator dari variabel atau konstruk. Suatu kuesioner dikatakan reliabel atau andal jika jawaban seseorang terhadap pernyataan adalah konsisten atau stabil dari waktu ke waktu. Untuk mengukur reliabilitas dengan uji statistik cronbach alpha lebih besar dari 0,60. Hasil uji menunjukkan nilai cronbach alpha untuk variabel gaya kepemimpinan tranformasional sebesar 0,943, variabel kompensasi sebesar 0,961, dan kepuasan kerja sebesar 0,870, artinya instrument penelitian adalah bersifat reliabel. Rangkuman dari hasil uji regresi linier berganda dapat ditunjukkan pada Tabel 10 .

Tabel 10.

Hasil uji regresi linier berganda

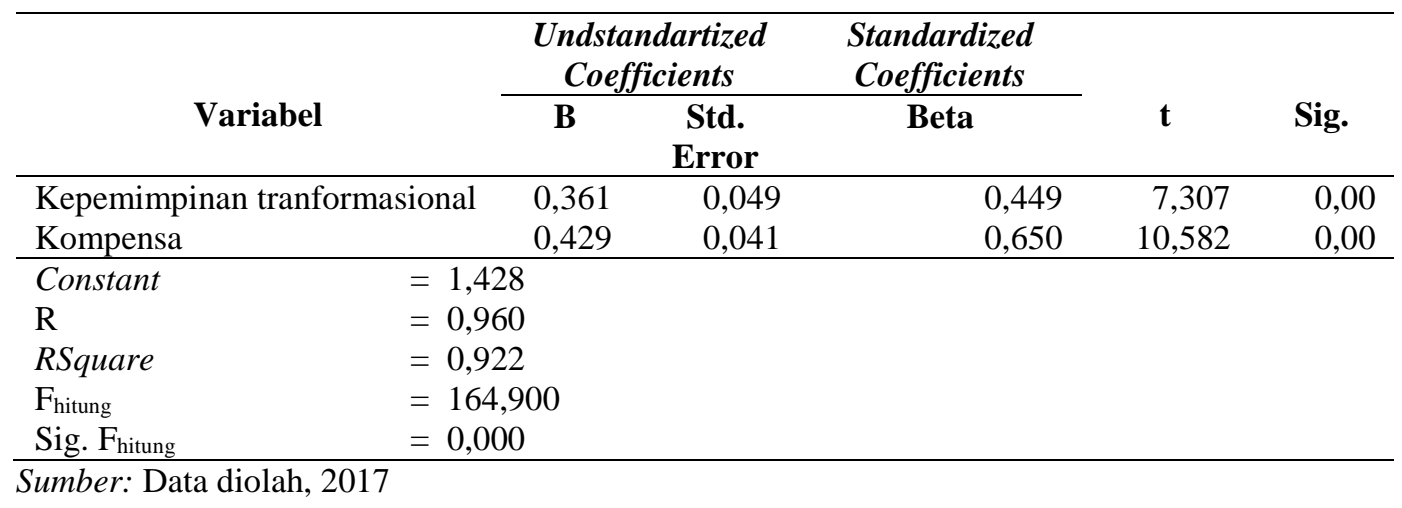


Analisis regresi linear berganda dilakukan untuk mengetahui pengaruh variabel bebas yaitu kepemimpinan transformasional dan kompensasi terhadap variabel terikat yaitu kepuasan kerja. Analisis regresi linear berganda dalam penelitian ini dilakukan dengan menggunakan bantuan aplikasi SPSS. Berdasarkan Tabel 10 dapat diketahui bahwa, persamaan regresi yang dihasilkan adalah sebagai berikut :

$$
\mathrm{Y}=1,428+0,361 \mathrm{X}_{1}+0,429 \mathrm{X}_{2}+\mathrm{e}
$$

Keterangan:

$$
\begin{array}{ll}
\mathrm{Y} & =\text { Kepuasan kerja } \\
\mathrm{a} & =\text { Bilangan konstanta sebesar } \\
\mathrm{X}_{1} & =\text { Kepemimpinan tranformasional } \\
\mathrm{X}_{2} & =\text { Kompensasi }
\end{array}
$$

Uji normalitas bertujuan untuk menguji apakah suatu data berdistribusi normal atau tidak. Penentuan normal atau tidaknya distribusi data dapat dilakukan pengujian dengan menggunakan statistik Kolmogorov-Smirnov. Hasil uji Kolomogorov Smirnov ditunjukkan pada Tabel 11.

Tabel 11. Hasil Uji Normalitas

\begin{tabular}{lr}
\hline & Unstandardized Residual \\
\hline $\mathrm{N}$ & 31 \\
Kolmogorov-Smirnov Z & 1,044 \\
Asymp. Sig. (2-tailed) & 0,226 \\
\hline Sumber: Data diolah, 2017
\end{tabular}

Uji multikolinearitas bertujuan untuk membuktikan atau menguji ada atau tidaknya hubungan yang linier (multikolinearitas) antara variabel bebas 
(independent) satu dengan variabel bebas yang lain. Adapun hasil dari uji multikolinieritas dapat ditunjukkan pada Tabel 12.

Tabel 12.

\section{Hasil Uji Multikolinearitas}

\begin{tabular}{clcc}
\hline No. & \multicolumn{1}{c}{ Variabel } & Tolerance & VIF \\
\hline 1. & Kepemimpinan tranformasional $\left(\mathrm{X}_{1}\right)$ & 0,740 & 1,351 \\
2. & Kompensasi $\left(\mathrm{X}_{2}\right)$ & 0,740 & 1,351
\end{tabular}

Sumber: Data diolah, 2017

Berdasarkan Tabel 12 dapat ditunjukkan bahwa, nilai tolerance untuk kedua variabel bebas lebih besar dari 0,1 sedangkan, nilai VIF kurang dari 10. Nilai tolerance untuk variabel kepemimpinan transformasional dan kompensasi masingmasing sebesar 0,740 dan 0,740, sedangkan nilai VIF masing-masing variabel adalah 1,351 dan 1,531. Jadi dapat dinyatakan bahwa, model uji tidak terdeteksi kasus multikolinearitas atau dapat dikatakan tidak ada multikolinearitas.

Uji heterokedastisitas dilakukan untuk mengetahui bahwa pada model regresi 21 terjadi ketidaksamaan varian. Untuk mendeteksi ada atau tidaknya heterokedastisitas digunakan model glejser. Kriteria untuk melakukan uji heteroskedastisitas ini adalah dengan melihat nilai signifikansi variabel, dimana nilainya harus lebih besar dari 0,05. Model ini dilakukan dengan meregresikan nilai absolute ei dengan variabel bebas. Adapun hasil dari uji heterokedastisitas ini dapat ditunjukkan pada Tabel 13.

Tabel 13.

Hasil Uji heterokedastisitas

\begin{tabular}{clcc}
\hline No. & \multicolumn{1}{c}{ Variabel } & thitung & Sig. \\
\hline 1. & Kepemimpinan tranformasional $\left(\mathrm{X}_{1}\right)$ & $-0,233$ & 0,827 \\
2. & Kompensasi $\left(\mathrm{X}_{2}\right)$ & $-0,546$ & 0,589 \\
\hline Sumber: & &
\end{tabular}
Sumber: Data diolah, 2017 
Berdasarkan Tabel 13 dapat ditunjukkan bahwa, kedua variabel bebas tidak berpengaruh signifikan terhadap nilai variabel terikatnya (absolute ei). Artinya, ditunjukkan dari nilai signifikansi yang lebih besar dari alpha 5 persen. Jadi dapat dinyatakan bahwa, model uji terbebas dari kasus heterokedastisitas atau dapat dikatakan tidak ada heterokedastisitas dengan nilai signifikan masing-masing variabel yaitu kepemimpinan transformasional dan kompensasi sebesar 0,827 dan 0,589 .

Uji koefisien determinasi dilakukan untuk mengetahui seberapa jauh kemampuan variabel bebas (independen) menerangkan variabel terikatnya (dependen). Nilai koefisien determinasi pada penelitian ini dapat dilihat dari nilai $\mathrm{R}^{2}$. Berdasarkan Tabel 10 nilai $\mathrm{R}^{2}$ sebesar 0,922, ini berarti sebesar 92,2 persen variabel kepemimpinan tranformasional dan kompensasi mempengaruhi kepuasan kerja, sedangkan sisanya sebesar 7,8 persen dipengaruhi oleh variabel lain yang tidak dimasukan dalam penelitian.

Uji kelayakan model (uji F) bertujuan untuk menguji apakah semua variabel bebas berpengaruh terhadap variabel terikat dan untuk mengetahui model regresi yang digunakan dalam penelitian ini layak uji atau tidak. Berdasarkan Tabel 10 diperoleh nilai dari signifikansi 0,000 yang lebih kecil dari 0,05. Ini berarti bahwa ada pengaruh antara variabel kepemimpinan transformasional dan kompensasi secara simultan terhadap variabel kepuasan kerja. Penyajian ini dilakukan untuk menguji hipotesis yang menyatakan bahwa kepemimpinan tranformasional $\left(\mathrm{X}_{1}\right)$, dan kompensasi $\left(\mathrm{X}_{2}\right)$, berpengaruh terhadap kepuasan kerja (Y) pada Restoran Warung Taulan Di Bali. 
Berdasarkan hasil uji t dan nilai signifikasi pada variabel kepemimpinan tranformasional $\left(\mathrm{X}_{1}\right)$ menunjukkan nilai sig lebih kecil dari 0,05 maka dapat disimpulkan bahwa, kepemimpinan tranformasional berpengaruh positif signifikan terhadap kepuasan kerja (Y). Hasil ini berarti semakin baik penerapan kepemimpinan tranformasional maka semakin tinggi kepuasan kerja, begitu sebaliknya semakin kurang baik penerapan kepemimpinan tranformasional maka semakin rendah kepuasan kerja.

Hasil penelitian ini sesuai dengan hasil penelitian sebelumnya yang dilakukan Yang (2012) bahwa kepemimpinan transformasional berpengaruh positif secara signifikan terhadap kepuasan kerja intrinsik dan ekstrinsik bawahan. Zahari (2012) mengatakan ada hubungan yang positif dan signifikan antara gaya kepemimpinan transformasional terhadap kepuasan kerja karyawan. Al-Swidi et al. (2012) mengatakan bahwa kepemimpinan transformasional telah terbukti memiliki efek signifikan pada kepuasan kerja karyawan melalui peningkatan persepsi pemberdayaan karyawan. Hasil ini juga dipertegas hasil penelitian Voon (2011) yang menyatakan bahwa kepemimpinan yang bergaya transformasional memiliki pengaruh positif terhadap kepuasan kerja karyawan. Kepuasan kerja adalah cara pandang seseorang baik yang bersifat positif maupun bersifat negatif tentang suatu pekerjannya. Perusahaan membutuhkan karyawan yang mampu bekerja lebih baik dan lebih cepat, untuk mendapatkan hal tersebut kepuasan kerja karyawan harus dipelihara dan diperhatikan.

Berdasarkan hasil uji t dan nilai signifikasipada variabel kompensasi $\left(\mathrm{X}_{2}\right)$ menunjukkan nilai sig lebih kecil dari 0,05 maka dapat disimpulkan bahwa, kompensasi berpengaruh positif signifikan terhadap kepuasan kerja (Y). Hasil ini 
berarti semakin tinggi kompensasi yang diberikan perusahaan maka semakin tinggi kepuasan kerja, begitu sebaliknya semakin kurang kompensasi maka semakin rendah kepuasan kerja.

Hasil penelitian ini sesuai dengan hasil penelitian yang dilakukan oleh Syah (2013) menyimpulkan bahwa kompensasi teruji berpengaruh positif terhadap kepuasan kerja dan motivasi kerja karyawan pada PT. Graha Raja Empat. Penelitian yang dilakukan oleh Erbasi dan Arat (2012) menyatakan bahwa sebuah hubungan yang positif dan signifikan tingkat tinggi ditentukan antara insentif keuangan yang digunakan dalam rantai makanan lokal dan kepuasan kerja karyawan. Penelitian yang dilakukan oleh Islam dkk. (2012) menyatakan bahwa ada hubungan positif antara kompensasi dan kepuasan kerja. Hasil penelitian ini juga didukung hasil penelitian Siregar (2011) menyatakan bahwa kompensasi berpengaruh positif terhadap kepuasan kerja.

\section{SIMPULAN DAN SARAN}

Berdasarkan hasil pembahasan, dapat disimpulkan sebagai berikut. Kepemimpinan tranformasional berpengaruh positif dan signifikan terhadap kepuasan kerja pada Restoran Warung Taulan di Bali. Artinya, semakin baik penerapan kepemimpinan tranformasional maka semakin tinggi kepuasan kerja, begitu sebaliknya semakin kurang baik penerapan kepemimpinan tranformasional maka semakin rendah kepuasan kerja. Kompensasi berpengaruh positif dan signifikan terhadap kepuasan kerja pada Restoran Warung Taulan di Bali. Artinya, semakin tinggi kompensasi maka semakin tinggi kepuasan kerja, begitu sebaliknya semakin kurang kompensasi maka semakin rendah kepuasan kerja. 
Berdasarkan simpulan tersebut, maka saran yang dapat diberikan adalah sebagai berikut: 1) pada variabel kepemimpinan tranformasional didapat nilai rata-rata terendah yang direspon oleh responden yaitu, pimpinan membantu karyawan dalam berkembang, oleh karena itu perlunya pimpinan untuk memberikan motivasi dan pencerahan bagi bawahan dengan pelatihan, 2) perlu peningkatan kompensasi apabila perusahaan mengalami peningkatan profit, 3) pemimpin perlu memberikan gaji yang sesuai dengan beban kerja yang dibebankan kepada karyawan.

\section{REFERENSI}

Alam, T.M., Taher A,. dan Kusdi R. 2013. Pengaruh Kepemimpinan Transformasional dan Budaya Organisasi Terhadap Kepuasan Kerja Pegawai (Studi Pada Pegawai Kantor Pusat PT Pelabuhan Indonesia III (Persero) Surabaya). Jurnal Administrasi Bisnis, 2(2): h: 1-6.

Al-Swidi, A.K., Nawawi, M.K., and Al-Hosam, A. 2012. Is the Relationship between Employees' Psychological Empowerment and Employees' Job Satisfaction Contingent on the Transformational Leadership? A Study on the Yemeni Islamic Banks. Journal Asian Social Science, 8(10): pp: 130150.

Alhempi, R.K. 2012. Kepemimpinan, Kompensasi dan Motifasi Serta Pengaruhnya Terhadap Kepuasan Kerja. Jurnal Media Riset Bisnis Dan Manajemen, 12: pp: 58-80.

Ardana, I.K., Mujiati,N.W., dan Utama, M. 2012. Manajemen Sumber Daya Manusia. Cetakan Pertama. Yogyakarta: Graha Ilmu.

Azeem, S.M. 2010. Job Satisfaction and Organizational Commitment among Employees in the Sultanate of Oman. International Journal of Psychology, 11(2): pp: 295-299.

Bass, B. M., Avolio, B. J., and Jung, D. I. 2003. Predicting Unit Performance By Assessing Transformational And Transactional Leadership. Journal of Applied Psychology, 88(2): pp: 207. 
Bushra, F., Ahmad, U., and Asvir, N. 2011. Effect of Transformational Leadership on Employees' Job Satisfaction and Organizational Commitment in Banking Sector of Lahore (Pakistan). International Journal of Business and Social Science, 2(18): pp: 261-267.

Diatmika, P. 2013. Pengaruh Kepemimpinan, Lingkungan Kerja dan Komunikasi Terhadap Kepuasan Kerja Karyawan. E-journal Universitas Udayana, 2(5): pp: 581-593.

Erbasi, A., and Tugay, A. 2012. The Effect if Financial and Non-Financial Incetives on Job Satisfaction: An Examination of Food Chain Premises in Turkey. International Business Research, 5(10): pp: 138-145.

Ghozali, I. 2006. AplikasiAnalisis Multivariate Dengan Program SPSS. Edisi Kedua. Semarang : Bagian Penerbit Universitas Diponogoro.

Gibson, L., M. Ivacevich., and James H. Donelly. 1996. Organisasi Behavior, Structure, Processes. 5 th ed., Bussiness Publication, inc, Texas.

Gorda, I. 2006. Manajemen Sumber Daya Manusia. Denpasar: Astabrata Bali bekerja sama dengan STIE Surya Darma Singaraja.

Handoko, T. 2010. Manajemen Personalia dan Sumber Daya Manusia, Edisi 2. Yogyakarta: BPFE.

Hasibuan, S. P. Malayu. 2007. Manajemen Sumber Daya Manusia. Edisi Revisi. Jakarta : Bumi Aksara.

Irawati, A., dan Bambang, S. 2010. Pengaruh Gaya Kepemimpinan Terhadap Kepuasan Kerja, Produktivitas dan Kinerja Organisasi. Jurnal Studi Manajemen, 4(1).

Islam, T., Zalifqar A., Ishfaq, A., Ashfaq., A., Muhammad, S., and Saher, K. 2012. Does Compensation and Demographical Variable Influence on Teachers Commitment and Job Satisfaction ? A Study of the Punjab, Pakistan. International Journal of Business and Management, 7(4):pp: 3543.

Luthans, F. 2005. Perilaku Organisasi, Edisi Sepuluh, Diterjemahkan oleh: Vivin Andhika Yuwono; Shekar Purwanti; Th.Arie Prabawati; dan Winong Rosari. Yogyakarta: Penerbit Andi.

Mangkuprawira, A. A., dan Prabu. 2002. Manajemen Sumber Daya Manusia. Bandung: Remaja Rosakarya. 
Martoyo, S. 2007. Manajemen Sumber Daya Manusia. Edisi Kelima. Yogyakarta: BPFE.

Maulizar, S. M., dan Mukhlis, Y. 2012. Pengaruh Kepemimpinan Transaksional Dan Transformasional Terhadap Kinerja Karyawan Bank Syariah Mandiri cabang Banda. Jurnal Ilmu Manajemen, 1(2): h: 58-65.

Mosadeghrad, A. M., dan Yarmohammadian, M.A. 2006. A Study Of Relationship Between Managers' Leadership Style And Employees' Job Satisfaction, (Online). Leadership in Health Services, 19(2): pp: 11-28.

Muhammad, M., Alamdar H. Aleem., and Wasim, H. 2012. Impact Of Job Satisfaction On Employee Performance: An Empirical Study Of Autonomous Medical Institutions Of Pakistan. African Journal of Business Management, 6(7): pp: 2697-2705.

Prabu, A. 2005. Pengaruh Motivasi Terhadap Kepuasan Kerja Pegawai Badan Koordinasi Keluarga Berencana Nasional Kabupaten Muara Enim. Jurnal Manajemen \& Bisnis Sriwijaya, 3(6): h: 1-25.

Rezvan, M. R., Aida, A., Maryam, E., and Shahram, A. 2013. Relationship Between Leadership Styles And Job Satisfaction Among Physical Education Organizations Employees. European Journal of Sports and Exercise Science, 2(1): h: 7-11.

Siagian, S.P. 2011. Manajemen Sumber Daya Manusia. Jakarta: PT. Bumi Aksara.

Simamora, H. 2006. Manajemen Sumber Daya Manusia. Edisi Ketiga, Cetakan Kedua, Yogyakarta: Penerbitan STIE YKPN.

Suastika, K.A., dan Surya, P. 2013. Pengaruh Kompensasi, Gaya Kepemimpinan Transformasional, dan Komunikasi Terhadap Kepuasan Kerja dan Semangat Kerja. E-Jurnal Universitas Udayana, 2(1): pp: 17-31.

Sugiyono. 2012. Metode Penelitian Bisnis. Bandung: Alfabeta.

Suyana Utama, M. 2007. Buku Ajar Aplikasi Analisis Kuantitatif. Denpasar: Sastra Utama.

Syah, H. 2013. Pengaruh Kompensasi terhadap Kepuasan Kerja Karyawan dan Motivasi Kerja Karyawan pada PT. Graha Raja Empat. Jurnal Ilmu Manajemen, 1(2): h: 462-471.

Taskina, A. 2009. Job Satisfaction of Faculty Member in Private Universities-In Context of Bangladesh. International Business Research, 2(4). 
Tsai, M.T., and Chun-Cheni, H. 2008. The Relationship Among Ethical Climate Types, Facets of Job Satisfaction, and The Three Components of Organizational Commitment: A Study of Nursein Taiwan. International Journal of Business Ethics, 80: pp:565-581.

Turkyilmaz, A., Akman, G., Ozkan Coskun., and Pastuzak, Z. 2011. Empirical Study of Public Sector Employee Loyalty and Satisfaction. Industrial Management and Data Systems, 111(5): pp:675-696.

Voon, M.L., M.C. L, K.S. Ngui1., and N.B. Ayob. 2011. The Influence Of Leadership Styles On Employees' Job Satisfaction In Public Sector Organizations In Malaysia. International Journal of Business, Management and Social Sciences, 2(1): h: 24-32.

Wahjosumidjo.2003. Kepemimpinan dan Motivasi. Jakarta Ghalia Indonesia.

Yang, Mu-Li. 2012. Transformational Leadership and Taiwanese Public Relations Practitioners Job Satisfaction and Organisation Commitment. Journal Social Behavior and Personality, 40(1): pp:31-46.

Zahari, I.B., and Shurbagi. 2012. The effect of Organizational Culture and the relationship between transformational leadership and Job Satisfaction in Petroleum Sector of Libya. International Business Research, 5(2): pp:8997. 